Zaklina Spalevic ${ }^{1}$

Sinergija University

Faculty of Law

Milos Ilic ${ }^{2}$

University of Pristina

Faculty of Technical Science

\section{Goran Filipic ${ }^{3}$}

Sinergija University

Faculty of Law
ORIGINAL SCIENTIFIC ARTICLE doi:10.5937/ekonomika1902051S

Received: May, 08, 2019

Accepted: Jun, 09, 2019

\title{
LEGAL AND ECONOMICAL ASPECTS OF INTELLECTUAL PROPERTY IN CYBER SPACE
}

\begin{abstract}
The use of information communication technologies as well as massive use of digital tools has influenced the daily activities of people. One of the most obvious indicators of rapid technological development is certainly the amount of information available in digital form. As a result of the use of digital tools and the Internet, a cyber space was created, which is the largest source of information. A variety of digital content is available to users of cyber space. In addition to content that is publicly available and can be used without any restrictions at the same time, a large percentage of digital information is protected by intellectual property rights and copyright and related rights. Beside aforementioned mechanisms for the protection of digital content, there is an evident increase in the number of copyright abuses. Abuse of copyright works causes huge economic damage to the authors of works as well as organizations. The aim of this paper is to analyze the current state of implementation of intellectual property protection mechanisms in the cyber space with a special emphasis on the application of these mechanisms in the Republic of Serbia. Mechanisms for the protection of intellectual property are examined through the domain of application of information communication technologies, legal aspects and registered abuses. At the same time, registered abuses were analyzed from the economic point of view both from the angle of the author of the work and from the perspective of the person who misused the subject work.
\end{abstract}

Key words: Cyber space, open source, copyright, abuses.

\footnotetext{
${ }^{1}$ zspalevic@sinergija.edu.ba

${ }^{2}$ milos.ilic@pr.ac.rs

${ }^{3}$ gfilipic@sinergija.egu.ba
} 


\title{
ПРАВНИ И ЕКОНОМСКИ АСПЕКТИ ИНТЕЛЕКТУАЛНЕ СВОЈИНЕ У ЦУБЕР ПРОСТОРУ
}

\begin{abstract}
Апстракт
Употреба информационо комуникационих технологија као и масовна примена дигиталних алата утицали су на свакодневне активности људи. Један од најевидентнијих показатеља брзог технолошког развоја свакако је количина информација достпуних у дигиталном облику. Као последица употребе дигиталних алата и Интернета настао је иубер простор који представља највећи извор информација. Најразличитији дигитални садржаји доступни су корисницима иубер простора. Поред садржаја који су јавно доступни и могу се користити без икаквих огранчењ а у исто време велики проченат дигиталних информација је заштићен правом интелектуалне својине и ауторским и сродним правима. Поред примене поменутих механизама заштите дигиталних садржаја евидентан је повећан број злоупотреба ауторских дела. Злоупотреба ауторских дела наноси велике економске итете ауторима дела као и организачијама. Циљ овог рада је анализа тренутног стањ а примене механизама заштите интелектуалне својине у иубер простору са посебним освртом на примену ових механизама у Републици Србији. Механизми заштите интелектуале својине сагледани су кроз домен примене информационо комуникачиноих технологија, правних аспеката и регистрованих злоупотреба. У исто време регистровне злоупотребе анализиране су са економског аспекта како из угла аутора дела тако и из угла лица које је злоупотребило предметно дело.
\end{abstract}

Кључне речи: Сајбер простор, лицение отвореног кода, циоуригхт, злоупотребе..

\section{Introduction}

Intellectual property can be regarded as having property of goods that have intangible character. In regard with this, the goods that belong to the intellectual property must to be intellectual products of the person they belong to. At the same time, intellectual property can also represent the product of the creativity and innovation of the person to whom it belongs. Observed from the origin, intellectual property encourages the creative side of man, and at the same time affects the shift of the boundaries of science and technology. In addition to the scientific and technical goods that are the product of intellectual creativity, intellectual goods also form a product of a creative human side and, by their very nature, influence the increase and enrichment of the world with literary and artistic works. If intellectual property is viewed from the domain of the author of the work or its creator, it can be said that it represents the specific rights of the author, inventor or holder of intellectual property rights. The key fact that is important to emphasize is that intellectual property is not a material property, but a set of rights and powers granted to the author or creator of the work. This practically means that the rights and powers are provided to the author and the creator of the intellectual good. The intellectual property rights frameworks are based on agreements and contracts that have emerged as a product of working groups at the international level, as well as on the 
legal norms defined in the national legislation of each country. The problem that arises with intangible assets that are protected by intellectual property rights is the way of their usage and protecion in the cyber space. A large number of users deliberately or unconsciously ignore the fact that the works to which they are accessed are copyrighted and can not be freely used. The availability of copyrighted works in digital form, such as scientific works, literary works, audio and video materials, various types of software, has made it very difficult to apply the concepts of copyright. For this reason the well-known traditional concept of copyright has to be adapted to the digitization of the content that need to be protected. In order to protect copyrighted works in digital form, new concepts have been created such as open source licenses, open source software, copy left licenses, Creative Commons Licenses (CCL), etc.

\section{Principles of intellectual property and copyrigh}

The intellectual property rights as a kind of protection of goods created as the ultimate product of individual or group creativity date back to the Constitution of the USA. Under article 1 of the USA Constitution, the Congress was given authority in the field of encouraging and advancing science and useful skills. This means that Congress have authority to provides the inventors and writers with exclusive rights over their works and inventions. The duration of these rights is limited, while the time limit is deferred in advance. Owing to the very early efforts in this area as well as the multilateral conventions covering this area, the area of intellectual property is one of the few branches of law that enjoys a high level of compliance in most of the legal systems. Within the scope of intellectual property, two categories can be distinguished. In these two categories all works that neet to be protected can be classified. These two categories are:

- Industrial property.

- Copyright and related rights

One of the representative examples of industrial property are patents. In addition to patents, companies' stamps, geographical indications, works created as a result of industrial design and even schemes of integrated circuits are included in the category of industrial property. From the other side category of copyright and related rights includes works of literature, science and art. If we observe number of actors that cooperate on the development of the intellectual property, in this category we can classify works that are the result of the intellectual and creative efforts of the individual. As was the case with the provisions of the US Constitution on intellectual property, as well as other countries and international organizations, for each case declared intellectual property no matter what category of intellectual property belongs, it defines a time limit on the duration of protection. For example, in the Republic of Serbia, the maximum duration of intellectual property protection that is in the form of a patent is 20 years. On the other hand, the maximum protection time of the stamps is 10 years with the possibility of unlimited renewal of protection. In practice, the protection of industrial property, for example, patenting an invention or product is achieved by conventional procedures. These procedures involve the recognition of a right or the registration of a particular patent. The very process of recognition of rights is exercised by the competent bodies for a particular area. In most cases, the mentioned area is the state in whose territory the work deserves to be created, which is the principle of territoriality. In fewer cases, 
protection can be done in the region. If considered in this way, the region would cover a wider area, and in such a way the protection itself would have a stronger effect. In the Republic of Serbia, the Intellectual Property Office is in charge of implementing the procedure for granting intellectual property rights.

Unlike industrial property where works are mostly of scientific or technical significance and where works have been created as a product of collective work, the work can be an original intellectual creation that can belong to a literary, scientific or artistic field. In order to classify the particular work in a copyright it must have an individual character. If we look at the domain of intellectual creation from the literary area here we could classify novels, poems, tales, and dramatic works. Foundations, patents, and more recently computer programs and databases can be considered under the domain of the scientific field. In the end, the muvies, music works, choreographic works, works of fine arts, works of architecture, applied values, sketches, photographs, etc. can be included in the works of art.

The process of assigning copyrights over some work and intellectual property rights must be covered by legal provisions. In the Republic of Serbia, provisions governing copyright are defined by the Law on Copyright and Related Rights ${ }^{4}$. According to this Law, the work of authorship is defined as a spiritual creation of the original character. The created spiritual creation must be expressed in a certain form. This practically means that regardless of the artistic, scientific or other value of the work itself, as well as its purpose, size, content and mode of expression, the work must comply with a particular form. The very form of work also relates to the permissibility of the public disclosure of its content.

The law also defines that every author has moral, property and other rights from the moment of creation of the author's work. Under the moral rights of the author, we can classify the author's right to acknowledge his work, as well as the right to make his name clear on each issued copy of the work. The author also has the right to publish his work. More precisely, according to this law, the author can determine the manner in which the subject matter will be published. Property rights include the right to reproduce the work, the right to obtain economic profit in the form of distribution of a work or its leasing, as well as the right to perform, broadcast and publicly communicate. A group of other rights includes the right to access a copy of the work, the right to follow, as well as the right to prohibit the presentation of the original specimen in the case of works of fine arts. This group includes the author's right to change the copy of the architectural work.

In addition to the copyright law, the Law also provides assignment of related rights to copyright. These rights are most often related to the legal protection of copyrighted works that include: the rights of the interpreters, the rights of the producers of phonograms, the rights of the producers of videogames, the right of the producer of the program, the right of the database manufacturer, the right of the first freelance publisher, the right of the publisher of printed editions to a special fee.

As can be seen from the above, in most cases protection related rights refers to audio and video records, works created in broadcasting, as well as to the domain of protection of organizational business and financial investments in the same. Generally speaking, authors of copyrighted works, as well as their successors and legal followers, are called copyright holders. All rights defined by the Law can be achieved by the holders in two ways: individually

${ }^{4}$ Law on Copyright and Related Rights, Official Gazette of the Republic of Serbia, no. 04/2009, 99/2011, 119/2012 I 29/2016 - decision CC. 
or collectively. Individual realization of a law practically means that a concrete person has created the original intellectual creation. In this case, the author himself, by the act of creating the work, has acquired the copyright and is not obligated to fulfill any other formalities such as registration or work deposit. If more authors worked on the creation of a work, where the work as such is an indivisible, shared copyright over the created work belongs to each author. The created work is called co-authoring. On the other hand, if the work is possible to be divided into individual parts where the authors were actively working, and afterwards, for the purpose of their joint use, all parts were combined into a joint work in which case each individual participant has a copyright over the part of work that is only his (Popovic, 2015). Collective copyright organization is never set up to earn profits. Holders of copyright or related rights through the organization for the collective exercise of rights may exercise the property rights and rights to claim compensation. Authors can claim compensation for their property that is copyrighted. The law stipulates that if the author realizes only property rights, this practically means that he will have the contract in the exclusive way to transfer all his rights to the organization. After the transfer of rights, the organization performs the affairs of concluding contracts with the users of the works on the non-exclusive transfer of these rights on behalf of the author. When it comes to exercising the right to remuneration of the organization on behalf of the copyright holder and at his request, he makes a payment from the user of the work. In such cases, an organization reserves the right to exercise control over the exploitation of copyrighted items. Pursuant to the Law in the event of a dispute, the organization has the right and is obliged to protect the interests and rights of the copyright holder before the court as an authorized person (PKS, 2018).

Holders defined in such way have certain rights and privileges that relate to the specific work of authorship. Rights and privileges allow the carrier to prohibit or authorize reproduction in all forms, including printing and sound recordings. Also, the holder of these rights may authorize the public performance and communication of the work. In the case of requests for the translation of works into other languages, as well as a request for eventual adaptation, the copyright holder decides whether or not he will approve changes.

In addition to the copyright law, the law also defines public ownership of some work. It can almost be said that the introduction of public ownership is as important as the existence of copyright. The reasons for the introduction of public ownership are varied and range from the domain of educational character through a democratic and economic one to the establishment of free competition. The role of public ownership is reflected in the creation of a positive atmosphere of free creativity, cultural diversity, innovation of individuals and groups, and the development of science and culture. The influence of the public domain in culture and science is particularly significant. In these areas, the public domain is reflected in the creation of cultural and scientific goods that will be available to everyone. In this way, the introduction of the public domain of work is protected from privatization and appropriation. An even more important feature of public ownership is the establishment of a balance between all available works and the exclusivity of intellectual property. According to the Berne Convention of 1886 , public works belong to works that have ceased copyright protection. This practically means that intellectual works and creations, after the termination of the validity of intellectual property rights, become publicly owned by intellectual property. In accordance with the Berne Convention, certain works can be classified as public property. Article 2, paragraph 4 of this Convention defines that official texts of legislative, administrative and legal nature, as well as official translations of such texts, can not be protected by copyright. In addition 
to official documents, Article 2, paragraph 8 of the Berne Convention stipulates that daily news and information are mandatory in the domain of public ownership. A large number of countries follow the convention as it is defined in order to limit copyright protection, while some countries are completing their national laws. In countries such as Algeria, China, France, Italy, and Korea under public ownership, they are considered at the very least laws and under legal acts, as well as court decisions. In some cases, some countries are extending the domains of the underlying public ownership to works produced or subsidized by the state or other public institutions. In the group of these countries we can include Brazil, Malaysia, USA. For example, Germany also approves the freedom to use and modify such documents. Judicial practice sometimes excludes works that have normative value, such as bank notes, official exams for certain professions, as well as opinions given by a judge. There are also states that do not apply the principles of this Convention, and examples of states recognized by Crown Copyright such as the United Kingdom and Australia. Countries that practice such protection are banned from public domain and given protection to them by copyright, while the holder of state protection (in the case of Australia) or queen (in the case of the United Kingdom) (Dusollier, 2010). If we observe daily news as one of the forms of public ownership, China, Costa Rica, Italy, Korea would be some of the countries that explicitly provide this rule. There are also cases where states based on national copyright laws transfer some of works from the copyrighted category to the domain of public ownership. By Article 11 of the Copyright Act, Chile defended that works obtained by expropriation by the state became public property. This practice was introduced at the beginning of the 1970s, when the Socialist government maintained the spirit of the times when expropriations for the public interest were a political strategy. Article 66 of the Copyright Act of Costa Rica as well as Article 45 of the same law of Brazil defines that works protected by copyright become public property after the death of the copyright holder if the holder has no legal successors.

\section{Open content licenses}

A large amount of information exchanged via the Internet service, as well as the diversity of published content, created the need for defining general licenses. These licenses define the way and the extent to which a particular copyright work can be used. This practically means that the privileges of using the copyright work will depend on the type of license that applies to it. The rules defined in these licenses author independently decides whether or not to allow commercial or non-commercial use of their work. Non-commercial use of the copyright work in practice does not necessarily mean the failure to realize economic profit for the author of the work. Practically, in this case, the author can still make an economic gain if he contracts with the publishing house. Based on such a contract, the publisher will pay a certain economic compensation to the author. In the process of licensing with open source licenses, authors must comply with the licensing procedure so that the work in question can be deemed to be truly licensed. Since for the use of a work that is licensed with open-content license does not require financial compensation, each such license contains a clause on the basis of which the license does not give any guarantee to the author of the work. Depending on the characteristics of the privileges offered by open source licenses, they may be split into general-type licenses or special-purpose licenses. Also, according to the nature of this license, they can be divided into licenses with small restrictions and licenses that clearly define the 
restrictions on the use of the work. Examples for Creative Community Licenses are licenses that clearly define restrictions on the freedom to use copyrighted work (Liang, 2015). In the domain of licenses for special purposes that defines special rights and privileges of use we can include licenses for software solutions. In regard with this, it can be said that when distributing the software, different licenses are defined depending on the privileges assigned to the user. As far as the open source sofware is concerned, it represents a type of sophisticated licenses for which the program code is available to anyone who wants to upgrade or develop it. Within these licenses various other divisions are defended, but the essence of free software remains the same. Their main differences are related to the use of source code in other projects as well as the use of the software generated by these new projects. Examples of open source software are: Linux, Open Office, apache web server. Some examples of such licences that are in use today are given below:

- GPL(General Public License). This type of license gives the user a very wide range of rights reflected in the possibility of redistribution and reverse engineering. This practically means that a user can make changes to the sofver. Although the user is allowed to make changes to the source code of the software, he must still fulfill certain conditions prescribed by this type of license. One of the basic conditions is that the user is obligated to publish all the changes made over the source code.

- LGPL (Lesser General Public License). This type of license is mainly applied to software libraries. This practically means that a user can distribute and modify the sofware so that everything connected to the library falls under the license itself and can be distributed so that the created application that uses the library can not be under this license.

- BSD (Berkeley Source Distribution). This type of license guarantees the end user complete autonomy over the software. In this way, the user is allowed to use the software and its source code as part of the encryption code of the closed code published under the proprietary license.

One of perhaps the best examples of using open source licenses is the GNU Movement or the GNU Community. This community is one of the first practical and successful initiatives that enable software users to freely use the advantages offered by the use of information communication technologies. The community itself started with activities in 1984. Its goal was to create an open source operating system called UNIX. For the GNU GPL license, one can freely say that it is one of the widely known licenses when the software industry is in question. The license itself defines the freedom to use the software, its copying, modification and distribution of all versions of the software released on the base version. The practical distribution of free software must be done under the same conditions under which the user originally received the software. $\mathrm{n}$ this way, GPL gives freedom to both the user and the software. The use of Creative Commons licenses was initially oriented to individuals (creators of creative works), however, with the increasing problems that the creative community encounters with regard to copyright protection, there is an increasing number of users of these licenses from legal entities and government agencies. All this testifies to the importance of this kind of creation and use of licenses. 


\section{Copyright infringement in cyberspace}

Popularizing the use of the Internet and its rapid expansion has contributed greatly to the opening up of a public access network, the ease of publishing content, easy finding it, and access to a large amount of information of different content in one place. A large amount of information has led to a severe differentiation of content that is protected by copyright from the content that is not protected. If it is compared with printed works as well as works on image and sound carriers where it is clearly indicated who is the copyright holder and whether the copyrighted work is protected, in the case of cyber space users are not always able to establish legal ways of downloading, modifying and later reproduction of a certain work. However, users of such content should always keep in mind that most of the content is subject to copyright. Generally speaking, two of the most significant forms and cases of potential infringement of intellectual property can be highlighted, such as software and multimedia content in digital form. Software and multimedia content as such on the one hand are most often subject to copyright protection, and are offered to Internet users with a certain fee. This group of content mostly includes audio and video materials, feature and documentary movies, software for commercial and home use, as well as multimedia tutorials created by an individual or organization (Spasic \& Stevanovic, 2015). In order to exchange and copy files without respect for copyright, services use different ways to to get through protocol and security mechanisms. Some of registred examples of copyright abuse are shown in the table 1.

Table 1: Registred abuses of copyright

\begin{tabular}{|l|l|l|l|l|l|}
\hline Year & Type & Acter & Amount & Verdict & Remark \\
\hline 2000 & File sharing & Napster & $\$ 36$ million & Quilty & $\begin{array}{l}\text { Music file } \\
\text { fharing }\end{array}$ \\
\hline 2014 & File sharing & BitTorrent & unknown & Dismissed & \\
\hline 2006 & File sharing & Finreactor & $\$ 700.000$ & Quilty & $\begin{array}{l}\text { Torrent web } \\
\text { site }\end{array}$ \\
\hline 2016 & File sharing & KickAssTorents & $\$ 31$ million & Quilty & $\begin{array}{l}\text { Torrent web } \\
\text { site }\end{array}$ \\
\hline 2012 & $\begin{array}{l}\text { Direct } \\
\text { download }\end{array}$ & Megaupload & $\$ 500$ million & Quilty & Kim Dotcom \\
\hline
\end{tabular}

In order to exchange and copy files without respect for copyright some services allow computers to directly interconnect without the intervention of the central server. One of the first music file sharing services appeared in 2000. This service was named Napster and enabled millions of users to exchange mostly copyright protected music files. After a series of litigation disputes, the service was shut down. The shutdown of this service did not discourage users of such services in attempts to create and use new ones. New services that are still in use in their work apply a different protocol that greatly prevents the prosecution of persons. This protocol is called BitTorrent. The very fact that a person involved in the exchange of files can not be processed has led to massive use of these services. These services in recent years are not limited just on sharing music files. Through this service, users can download almost all digital content from music through video to various types of software. That the torrent file was not illegal is proved by the Iowa court judgment in 2014, by which 
this court dismissed the massive lawsuit against BitTorrent users as unfounded. In favor of rejection, the fact was that it was not possible to prove the link between the torrent file and the Internet pirate (Van der Sar, 2017).

On the other hand, a large number of court verdicts against various torrent file sharing services testify to the extent to which the fight against such a copyright infringement has persisted. One example is the court case which is conducted in front of the court in Finland. Namely, following the police's downfall on the Bit Torrent website named Finreactor, eleven people were arrested. For the damage caused by the distribution of the copyright protected digital material, they were ordered to pay 500.000 euros in damages and 200.000 euros on behalf of the court costs. After the series of appeals brought by the accused, the whole process reached the Supreme Court of Finland, which once again confirmed the first instance verdict (Enigmax, 2017). Six EliteTorrents.org site administrators, after taking control of the site by the US Federal Bureau of Investigation, pleaded guilty to participation in a conspiracy involving criminal offenses of copyright infringement and publication of works before their commercial release. After the trial, they were sentenced to imprisonment, house arrest and fines. Prison sentences are based on criminal law (Yoskowitz, 2017). The arrest of Artem Vaulin owner of KickAssTorents was carried out in a coordinated action by the IRS and Homeland Security. In the process of obtaining the facts that led to the arrest, Facebook and Apple also participated in the service through which the service was created the IP address of the computer from which Artem approached. The same IP address was used to purchase on iTunes as well as to access the KickAssTorents Facebook page. It was also associated with a Bitcoin account sponsored by donors to support the KickAss Torrent (Sandoval, 2017). Artem is charged for copyright infringement and money laundering. In an account opened in a Lithuanian bank to save money collected from illegal transactions over a period of seven months, investigators recorded just over $\$ 31$ million. It is estimated that the torrent service itself has distributed various digital content worth over one billion dollars during its existence. Vaulin was arrested by Polish authorities on July 20th, 2016. The United States District Office of Northern Illinois filed an unsealed complaint charging him with conspiracy to commit criminal copyright infringement, conspiracy to commit money laundering and two counts of criminal copyright infringement. Vaulin faces up to 20 years in prison.

Direct downloading of copyrighted files is another way of copyright violation. Some of the examples of websites for direct download are Mega.co.nz, FileShare.link, etc. In an indictment against Megaupload owner Kim Dotcom and three directors arrested in New Zealand in 2012, it is alleged that thay damaged copyright holders of various flames, series and other content for more than \$ 500 million. They were arrested on charges of US officials (McCormick, 2015). The indictment alleges that Dotkom, who is a native of Germany with his current place of residence in Hong Kong and New Zealand, earned \$ 42 million in 2010. It is interesting that in addition to two places of residence, Dotcom has a dual citizenship of Finland and Germany. Experts estimate that owners are based on premium subscription orders for this service earned \$ 175 million (Gallagher, 2012).

One of the copyright infringement trends that has emerged with the development of higher speed Internet is online streaming. This principle is in use when a user is watching digital content in the form of different videos, series, flames, shows, etc. Also, in this group of sites we can includes sites that allow tracking of sports or other channels for which a monthly subscription is required. Practically, sites providing such services are usually registered in countries where copyright protection is not overly developed and intellectual 
property infringement is tolerated. The court practice have been devided with regard to copyright infringement by viewing digital content through streaming. The court in Cologne has established on the basis of IP address tracking that the owner of the same has accessed copyrighted works, so it has been processed. The specificity of this case is that it was not about actually downloading content but streaming. The law office, which launched this dispute against a large number of users (about 60000), has instrumented its process by the fact that when the user calling video streams, digital content caches. This cached digital content can later be copied or recorded on the local computer memory (Dusollier, 2014). Namely, in these disputes, it remained contested whether the law office had the right to monitor users in any way and to record IP addresses of users who visited a particular portal. Namely, the court in Hamburg ruled that the privacy rights of users were violated with this move of a law office. In the explanation of the decision, it was stated that the entire process and violation of the privacy rights against the users of this streaming channel was led by the law office for the acquisition of financial gain. The introduction of this decision in court practice represents the success of the streaming portal users.

\section{Criminal offenses against copyright in the Republic of Serbia}

By defining criminal offenses, the fulfillment of the protection of intellectual property rights is carried out within the legal system of a country. The processing of works aimed at the damage or theft of intellectual property in the Republic of Serbia falls within the scope of work of the Special prosecutor's office for combating agains high-tech crime. This office of the prosecutor performs the tasks of prosecution of criminal offenses established by the Criminal Code, which are directed against the security of computer data. In addition to this type of criminal offense, the prosecution's activities include all those acts in which computers, computer networks as well as computer systems occur as objects or means of committing criminal offenses. For example, in such works can be included works against intellectual property, acts against property, economy and even traffic. Also, the prosecution's work is based on the processing of copyright infringement cases, if it is a piracy for commercial purposes, with the number of multiplied copies of the work exceeding 2000, or by an investigation it is found that the author has suffered material damage in the amount of over one million dinars. If computers and computer networks are used for the purpose of committing crimes against human rights and freedoms, as well as for the purpose of violating sexual freedom, public order and peace, as well as constitutional order and security, the Prosecutor's Office is obliged to prosecute such acts ${ }^{5}$. The processing of persons accused of endangering copyright and related rights covered by this law is part of judicial practice in the Republic of Serbia for many years. In 2012, 219 persons were registered for criminal offenses against intellectual property. Of the total number of reported cases for a criminal offense, an unauthorized exploitation of an author's work or subject-matter of a related right from the article. 199. Criminal code is reported 24 persons $^{6}$. During 2013, due to a criminal offense, the unauthorized exploitation

${ }^{5}$ Criminal Code, "Sl. glasnik RS ", no 85/2005, 88/2005 - corection., 107/2005 - corection., 72/2009, 111/2009, 121/2012, 104/2013, 108/2014 i 94/2016

${ }^{6}$ Republic of Serbia Republic Public Prosecutor's Office, "The work of the Public Prosecutor's Office on combating crime and protection of constitutionality and legality in 2012" 
of a copyrighted work or subject of related rights under Article 199 of the Criminal code filed a criminal complaint against 19 persons. During 2014 and 2015, due to a criminal offense, unauthorized exploitation of an author's work or subject of a related right under Article 199 of the Criminal Code against 12 or 10 persons was filed criminal charges. During 2016, criminal charges were filed against 4 persons for the same criminal offense ${ }^{7}$. A smaller number of filing criminal charges can be discussed from different aspects. One of the aspects may be that the number of such work is lower, and therefore the number of applications is smaller, while the other aspect may be an indicator of the poor involvement of state authorities in solving this problem.

One of the examples from the case law is also the judgment of the District Court in Belgrade K1.vtk.br.19 / 08 of 10 October 2008. With this verdict Ž. J. (36) and S. M. (35) were found guilty of Internet piracy. During the investigative procedure, they were charged for the unauthorized sale of various author's works through the wireless connection over the territory of Kraljevo municipality during three years. During 2005, they even founded the company "EXCALIBUR COM D.O. O" through which they received cash payments for the services they offered. After submitting proof of payment, users were able to download copies of various copyrighted works. With this verdict, the defendants were sentenced to a suspended sentence of six months' imprisonment. With the same verdict, the verification deadline was two years.

Another example of the same criminal offense is the judgment of the District Court in Belgrade, K1.vtk.br.44 / 08 of 28 November 2008, by which the criminal offense of piracy was found guilty by M.S. (30) from Belgrade. M. S was also in the period of three years (01.01.2005-03.09.2008) multiplied different copyrighted works for the purpose of gaining a property benefit. The entire process of multiplication and distribution was done at the address of his place of residence, while communication with clients was done via e-mail created using the yahoo mail service. At the time of the arrest of M. S, two computers were seized. In addition to the computer, at the time of the arrest he also had 10,327 pieces of multiplied optical discs, which contained unauthorized multiplication of author's works. The most numerous works were in the form of films, television series, music, comics and other multimedia content (Prlja, et. al. 2012).

In one of the cases, the accused claimed that he was a collector, and that he had collected confiscated flames for many years. He also claimed that some of the films were transferred from VHS to DVX for easy storage, and that he personally made wrappers. However, although he defended with the fact that films were not intended for the acquisition of material gain, the investigation showed that a large number of folders and electronic catalogs were found on the hard disk of the computer. The key moment for the indictment was finding ads in which the sale of DVX disks with the same titles found in the electronic catalogs was offered. For each of the titles, it was stated that the quantity was not limited, the price and the phone number of the defendant were also indicated, through which the interested customers can contact him.

\footnotetext{
${ }^{7}$ Republic of Serbia Republic Public Prosecutor's Office, "The work of the Public Prosecutor's Office on combating crime and protection of constitutionality and legality in 2016"
} 


\section{Anti - Counterfeiting Trade Agreement}

The amount of digital content available in the cyber space has allowed a large number of abuses of intellectual property rights protected. Today, there is almost no work that can not be found in a cyber space and used as such, both with respect to copyright and abuse of copyrights. How big a problem for the intellectual community is the abuse of copyright work in the cyber space is also testified by international agreements designed to devise an effective system of intellectual property protection. These agreements must be adapted to the times in which digital technologies are far more represented than traditional paper forms of publication. One in a series of such agreements is ACTA an international agreement aimed at protecting intellectual property. Negotiations on the agreement were concluded on October 1, 2011 by signing in Tokyo. Signatories to the negotiations were Singapore, the United States, Morocco, Canada, Japan, New Zealand, and South Korea. Several months after signing the agreement, the European Union, more precisely 22 member countries, joined. In addition to the fact that the $22 \mathrm{EU}$ member states have signed an agreement, after a series of disagreements, the EU Parliament is on 4.7.2012. refused this agreement. Of the total number of Members of the European Parliament, 478 MPs voted against the agreement, 39 were for ratification, while 165 MPs remained abstained ${ }^{8}$.

Work on this agreement and its creation from the very beginning was covered with vast secrets. The secrecy of this agreement is enhanced by the fact that the world's leading institutions such as the UN, the WTO or the SOIS were not involved in the first negotiations. The first negotiations on this agreement began in 2006 between US and Japanese officials. Later, the largest and most powerful countries in the world, such as the EU, joined the negotiations. Official negotiations began in 2007. At the same time, some countries that have been involved in informal negotiations are leaving official negotiations, which express their opposition to the idea of the entire agreement. What might have caused the greatest suspicion of the intention of such an agreement was that certain countries declared the content of the agreement a state secret. In favor of the lack of trust under this agreement, the George W. Bush and Barack Obama administrations refused to make ACTA versions of the negotiated agreements available to the public. In addition to the United States, the European Union has also proclaimed negotiations with state secrets. Canada has, for example, disclosed the case as a public name only, while the contents remained secret. New Zealand, as one of the participants in the negotiations, made promises that the secrecy of these negotiations will be in effect for a shorter period of time, more precisely when the partner countries do not get the permission to publish the data. However, the negotiations themselves remained a state secret until their completion ${ }^{9}$. Also important fact is that the content of this agreement will certainly remain a secret if the Wikileaks did not disclose the existence of negotiations in 2008 and part of the content of the agreement.

The basic provisions of the ACTA agreement expressed in the pramble were legitimate copyright protection, intellectual property rights as well as the prevention of falsification of intellectual property and piracy. The ultimate effect of the signed agreement was the

\footnotetext{
${ }^{8}$ BBC News, „Acta: Controversial anti-piracy agreement rejected by EU“, available on: http:// www.bbc.com/news/technology-18704192, date: 10.12.2017.

${ }^{9}$ Tech Liberty NZ, „Acta - The NZ Official Information Requests“, available on: http://techliberty. org.nz/acta-the-nz-official-information-requests/, date: 12.12.2017.
} 
legal method contrary to the provisions defined in regional and international human rights documents. The basic human rights violated by this agreement were the right to privacy, the right to freedom of expression, access to medicines, and the right to a fair trial. The solution to this counterfeit agreement is aimed at forcing Internet companies and Internet service providers to monitor the activities of their online users, as well as censor content. One member of this agreement provides an opportunity for the signatory countries to monitor online users through the competent authorities. The group of supervised users include users of cyber space suspected of having violated and actively violating the principles of copyright protection. This agreement also introduces a global agency that would deal with the suppression of piracy through electronic services. All this indicates that the ACTA concept of a three-tier agreement, regardless of the importance of copyright protection, puts emphasis on restricting the freedom of individuals and enabling the creation of financial profits for individual companies. The limitations on medicines and biotechnology, in addition to the fact of neglecting humanity, also reflect on the impact of the financial lobby of large companies on the creation of this agreement.

\section{Conclusion}

The protection of intellectual and copyright law has been a challenging issue from the mere start of development of systems for protection from unauthorized usages. By digitizing most of the content and massive use of digital work in cyberspace, the problem of protection has become even more complex. This problem is reflected in a constant struggle in which authors must protect their works from unknown users that can be anywhere in the world. The economic gain of counterfeit content, especially software and multimedia, can pass serious numbers. Pirates are increasingly attacking commercial software for whose use it is necessary to pay the license. Enabling the use of such software without the purchase of a license causes great harm to the producers of these licenses. On the other hand, counterfeiting of multimedia content, junk hoarding or publishing before the official premiere can cause great problems for the authors of the work, and at the same time make great profit to the pirates. The presence of copies of copyrighted works in cyberspace, the widespread and undisturbed work of the file sharing service as well as the ever-increasing streaming services are one of the indicators that there has been very little legal action to combat this type of crime. It is precisely for these reasons that the individual legal system of each country, as well as of international organizations, must further engage in the suppression of any possibility of abusing copyright rights and works protected by intellectual property rights.

\section{References}

Diligenski, A. (2014) Examining IP Addresses and Privacy Concerns for Copyright Violations by Watching Redube Streaming, Personal Data Protection, available at: http://partners-serbia.org/privatnost/blog/ispitivanje-ip-adresa-i-ugrozavanjeprivatnosti-zbog-krsenja-autorskih-pravagledanjem-streaming-a-slucajredtube/, date: 07.12.2017.

Dusollier, S. (2010). Scoping study on copyright and related rights and the public domain. WIPO. 
Enigmax, Te Pirate Bay Trial: Understanding Finreactor“, Torrent Freak, available at: https:// torrentfreak.com/the-pirate-bay-trial-understanding-fnreactor-090223/, date: 05.12.2017.

Gallagher, S. (2012) Te Fast, Fabulous, Allegedly Fraudulent Life of Megaupload's Kim Dotcom“, Wired, available at: https://www.wired.com/2012/01/kimdotcom/, date: 07.12.2017.

Laurent, A.M. (2004). Understanding Open Source and Free Sofware Licensing. O’Reilly Media, Inc, 2004.

Liang, I. (2005). Guide to Open Content Licenses, Piet Zwart Institute e for postgraduate studies and research Willem de Kooning Academy Hogeschool Rotterdam.

McCormick, R. (2015). Megaupload founder Kim Dotcom can be extradited to the US to face copyright charges, Te Verge, available at: https://www.theverge. com/2015/12/22/10655646/megaupload-founderkim-dotcom-can-be-extraditedto-the-us-to-face, date: 05.12.2017.

PKS - Belgrade Chamber of Commerce, Copyright and Related Rights, Available at: http://www.kombeg.org.rs/aktivnosti/c_privprav/Detaljnije.aspx?veza=13054, date: 05. 09.2018.

Popovic, D. (2015). Critical review of the related rights protection of the publisher: protection of economic or cultural enterprises. Journal of Legal and Social Sciences, 63(1).

Prlja, D., Reljanovic, M. \& Ivanovic, Z. (2012). Internet law. Institute for Comparative Law Belgrade.

Sandoval, G. (2017). An interview with alleged Kickass Torrents founder in his jail cell in Poland, Te Verge, available at: https://www.theverge.com/2017/5/23/15681160/ kickasstorrents-founderartem-vaulin-interview-bittorrent, date: 06.12.2017.

Spasic, V. \& Stevanovic, B. (2015). Demonstrating digital infringements of intellectual property rights - a review of the Anglo-Saxon legal system. In Proceedings of the Faculty of Law in Nis.

Van der Sar, E. Judge Understands BitTorrent, Kills Mass Piracy Lawsuits, Available at: https:// torrentfreak.com/judge-understands-bittorrentkills-mass-piracylawsuits-140130, date: 06.12.2017.

Yoskowitz, A., Elite Torrents admin gets 18 months in jail, News by aferdawn, available at: http://www.aferdawn.com/news/article.cfm/2008/09/10/elitetorrents_admin gets_18_months_in_jail, date: 05.12.2017. 